\title{
EFFECT OF CARAWAY ESSENTIAL OIL ON THE ANTIOXIDANT AND ANTIMICROBIAL ACTIVITY OF CHITOSAN FILM
}

\author{
Nevena M. Hromiš, Sandra N. Bulut*, Vera L. Lazić, Senka Z. Popović, Danijela Z. Šuput, Siniša L. \\ Markov, Žužana G. Vaštag, Natalija R. Džinić \\ University of Novi Sad, Faculty of Technology, Bulevar Cara Lazara 1, 21000 Novi Sad, Serbia
}

*Corresponding author:
Phone: +381214853702
Fax: +381216350262
E-mail address: sandra.bulut@gmail.com

\begin{abstract}
The aim of this study was to evaluate bioactivity of chitosan film with incorporated caraway essential oil by measuring antioxidant and antimicrobial activity. A Fourier transform infrared spectroscopy was used to determine the potential interaction of functional groups of chitosan film and incorporated caraway essential oil. New detected peaks and main shifts in the peaks of chitosan spectra are attributed mainly to presence of $s-(+)$-carvone and limonene, the main components of caraway essential oil. The antioxidant activity of chitosan film was analyzed by DPPH method. Chitosan film without incorporated caraway essential oil showed the lowest scavenging ability $(29.95 \%$, after $24 \mathrm{~h})$. The addition of different concentrations of caraway essential oil into chitosan film significantly enhanced antioxidant activity of pure chitosan film, reaching the maximum of $95 \%$. ASTM E 2149 - 01 method was performed to evaluate the antimicrobial activity of chitosan films. The reduction of bacteria cell number in contact with examined films was tested on Gram-positive bacteria Staphylococcus aureus and Listeria monocytogenes and Gram-negative bacteria Escherichia coli and Salmonella Typhimurium. The most sensitive bacteria was Staphylococcus aureus and the most resistant bacteria was Salmonella Typhimurium for all tested films. These results suggested that incorporation of caraway essential oil into chitosan film significantly improved its antioxidant and antimicrobial activity. The film showed a great potential to be used as an active packaging material.
\end{abstract}

Key words: chitosan film, caraway essential oil, antioxidant activity, antimicrobial activity

\section{INTRODUCTION}

Biopolymer films have been the focus of the worldwide attention for the past two decades because of their great ability to slow down moisture, oxygen, aromas and solute transports, and of their environmental advantages, such as biodegradability and compatible renewable resource (Ruiz-Navajas et al., 2013).

Chitosan is a semi natural polymer obtained by deacetylation of chitin, and it has interesting properties such as excellent film forming ability and gas and aroma barrier properties at dry conditions, which makes it a suitable material in designing food coatings and packaging structures
(Portes et al., 2009; Martins et al., 2012; Ruiz-Navajas et al., 2013). Pure chitosan films were described as generally cohesive, compact with smooth surface without pores or cracks (Hromiš et al., 2014). There are many literature data about chitosan high antioxidant and antimicrobial activity and ability to inhibit the growth of a wide variety of fungi, yeasts and bacteria (Portes et al., 2009; Siripatrawan and Harte, 2010). A higher antimicrobial efficiency of chitosan against Gram-positive than Gram-negative bacteria has been reported (Coma et. al., 2003; Wu et al., 2004; Pranoto et al., 2005; Gupta and Haile, 2007). Chitosan was studied as a 
coating for different food products, such as sausages, cheese, fish and seafood, fruit and vegetables (Sathivel et al., 2007; Casariego et al., 2008; Almenar et al., 2009; Fajardo et al., 2010; Krkić et al., 2013).

Antioxidant and antimicrobial activity of pure chitosan film can be improved by incorporating active compounds in the film matrix (Pranoto et al., 2005; Martins et al., 2012). Essential oils have been shown to possess antimicrobial and antioxidant properties due to their composition that includes active terpenoids and phenols which have ability to scavenge very reactive free radicals (Altiok et al., 2010; Siripatrawan and Harte, 2010). It is known that essential oils have natural antimicrobial properties and can control the growth of pathogenic microorganisms and in this manner essential oils can extend the shelf life of foods (Ruberto and Baratta, 2000; Ruiz-Navajas et al., 2013). Wider application of essential oils in film is difficult to achieve due to their influence on organoleptic food properties (Ruiz-Navajas et al., 2013). Since it takes quite a large concentration of essential oils, in the case of direct incorporation of substances in food to achieve the antimicrobial and antioxidant activity, numerous studies have shown that the incorporation of essential oils in biopolymer films for the purpose of obtaining an antimicrobial effect, give very good results with gradual release of active compound (Coma et al., 2002; Kurek et al., 2013; Ruiz-Navajas et al., 2013). The main components of caraway essential oil, that are present in the largest amount, are s-(+)-carvone and limonene. Their antioxidant and inhibitory effect on the growth of various microorganisms were reported (Bailer et al., 2001; Aggarwal et al., 2002; Wei and Shibamoto, 2007; Samojlik et al., 2010). Unfortunately, there was a low interest in caraway essential oil in the literature, as compared with other essential oils.

The aim of this work was to improve antioxidant and antimicrobial activity of chitosan-based film by incorporating different concentrations of caraway essential oil into the film. Obtained films were tested for their structural properties, as well as their antioxidant and antimicrobial activity.

\section{MATERIAL AND METHODS}

\section{Reagents}

Commercial chitosan powder from crab shells, highly viscous (DD around $80 \%$ ); 2,2-Diphenyl-1-picrylhydrazyl (DPPH); glacial acetic acid and Tween 20 were obtained from Sigma-Aldrich Chemical Co. (St. Louis, Missouri, USA). Commercial caraway essential oil (produced by steam distillation) was obtained from Herba doo (Belgrade, Serbia).

\section{Film preparation and visual examination}

Chitosan film forming solution was prepared by dissolving chitosan powder in $1 \%(\mathrm{v} / \mathrm{v})$ acetic acid to reach chitosan mass per volume ratio of $10 \mathrm{~kg} / \mathrm{m}^{3}$. Solution was left stirring over night on a magnetic stirrer to dissolve chitosan. Vacuum filtration of chitosan solutions was performed to remove undissolved particles. Caraway essential oil in volume concentration of 1,2 and $3 \%(\mathrm{v} / \mathrm{v})$ and wetting agent Tween 20 (50\% of essential oil volume) were then added, solution was heated in a water bath to $60{ }^{\circ} \mathrm{C}$, stirred with laboratory stirrer, then homogenized at $20000 \mathrm{rpm}$ for $2 \mathrm{~min}$, left for $2 \mathrm{~min}$ and again homogenized at $20000 \mathrm{rpm}$ for 2 min using Silent Crusher-M homogenizer (Heidolph, Germany) to obtain white homogenous emulsion. Emulsions were casted on Petri dishes covered with teflon coating and left to air dry $\left(23 \pm 3{ }^{\circ} \mathrm{C}\right.$, $50 \pm 10 \% \mathrm{RH}$ ) on a horizontal surface. Films were labeled as follows: $\mathrm{C}$, for chitosan film without essential oil; CC, for chitosan film with $1 \%(\mathrm{v} / \mathrm{v})$ of caraway essential oil; CC2, for chitosan film with $2 \%(\mathrm{v} / \mathrm{v})$ of caraway essential oil and CC3, for chitosan film with $3 \%(\mathrm{v} / \mathrm{v})$ of caraway essential oil.

Visual appearance of all produced films was described in relation to their application as packaging material.

\section{FTIR spectra}

The attenuated total reflection Fourier transform infrared spectra (ATR-FTIR spectra) were recorded at room temperature on a Nicolet iS10 Fourier transform infrared spectroscopy (FTIR) spectrometer (Thermo Fisher Scientific, MA, 
USA). All spectra were taken in the spectral range of $4000-500 \mathrm{~cm}^{-1}$ with a 4.0 $\mathrm{cm}^{-1}$ resolution. Software Omnic 8.1. (Thermo Fisher Scientific, MA, USA) was used to operate the FTIR spectrometer and collect all the data.

\section{Antioxidant activity}

The potential antioxidant activity of the films was assessed on the basis of scavenging the stable DPPH • free radical. The DPPH• scavenging activity of the films was determined according to the assay described by Morales and Jimenez-Perez (2001), with some modifications. In brief, $100 \mathrm{mg}$ of film was placed in a flask containing $2.4 \mathrm{~mL}$ of daily prepared 0.16 $\mathrm{mM}$ ethanolic solution of DPPH and was stirred for $2.5 \mathrm{~h}, 4 \mathrm{~h}$ and $24 \mathrm{~h}$, at room temperature. The controls were without the presence of films. In each sample, the remaining $\mathrm{DPPH} \cdot$ concentration was determined after removing the solid film by measuring the absorbance at $520 \mathrm{~nm}$ using T80/T80+UV-Vis spectrophotometer (PG Instruments Ltd., United Kingdom). The AA of the films was expressed as a percentage and calculated using the following equation:

\section{$A A(\%)=((1-[D P P H \bullet] t) \times 100) /[D P P H \cdot] c$}

where [DPPH॰]t is the concentration of $\mathrm{DPPH} \bullet$ in the tested sample and [DPPH $\bullet$ ]c is the concentration of $\mathrm{DPPH} \cdot$ in the respective blank.

Measurements were done on freshly casted films, after drying.

\section{Antimicrobial activity}

Antimicrobial activity was tested according to the ASTM E2149 (2001) method. Grampositive (Staphylococcus aureus and Listeria monocytogenes) and Gram-negative bacteria (Escherichia coli and Salmonella Typhimurium) were used as test organisms. Fresh inoculants for antimicrobial assessment were prepared on nutrient agar (Merck, Germany) at $37^{\circ} \mathrm{C}$ for $24 \mathrm{~h}$. The incubated test culture was diluted using a sterilized $3 \mathrm{mM}$ phosphate buffer $\left(\mathrm{KH}_{2} \mathrm{PO}_{4} ; \mathrm{pH} 6.8\right)$ to give a final concentration of $1.5-3 \times 10^{5} \mathrm{CFU} / \mathrm{mL}$. The prepared bacterial suspension was used in the next steps.
Film samples were treated with UV lamp (Kruss, Germany): $254 \mathrm{~nm}, 1 / 2 \mathrm{~h}$ for one side of film, cut into test pieces, which had contact surface area of $58 \mathrm{~cm}^{2}$ and transferred to a $250 \mathrm{~mL}$ Erlenmeyer flask containing $50 \mathrm{~mL}$ of the bacterial suspension. All flasks were capped loosely and shaken for $24 \mathrm{~h}$ at room temperature and $120 \mathrm{rpm}$ using a Wrist Action incubator shaker. At different contact periods $(3 \mathrm{~h}$ and $24 \mathrm{~h}), 1 \mathrm{~mL}$ of the bacterial suspension was withdrawn, serial diluted and plated in Tryptone soya agar (Merck, Germany). The inoculated plates were incubated at $37{ }^{\circ} \mathrm{C}$ for $24 \mathrm{~h}$, and colonies were counted. The average values of the duplicates were converted to $\mathrm{CFU} / \mathrm{mL}$ in the flasks by multiplying with the dilution factor. The antimicrobial activity was expressed as percentage reduction of the organism after contact with the test specimen, compared to the percentage reduction of the control film.

\section{Statistical analysis}

The data were analysed using OriginPro 8 (OriginLab Corporation, Northampton, MA, USA). All data were presented as mean value with their standard deviation (mean $\pm \mathrm{SD}$ ). Analysis of variance (ANOVA) was performed with a confidence interval of $95 \%(p<0.05)$. Means were compared by the Tukey's test.

\section{RESULTS AND DISCUSSION}

\section{Visual examination}

Visual examination of the C film showed that the film was pure, transparent, flexible, compact and colorless. Chitosan film with different concentrations of caraway essential oil (CEO) showed significant difference in appearance. CC was colorless, similar to pure chitosan film, but more turbid. The CC2 film was yellow with white print, probably as the result of agglomeration of emulsified droplets of CEO during film drying. The CC3 film was the yellowest and a large tinge of oil released from the film was noticed on the plate. All films with CEO were flexible, soft and turbid, with odor of caraway.

\section{FTIR spectra}

FTIR spectra were used to evaluate the effect of incorporation of CEO at different 
concentrations in chitosan film. In addition, the typical peaks of $\mathrm{s}-(+)$-carvone and limonene, main components of CEO responsible for its bioactivity, were identified in the FTIR spectra of CEO. Typical bonds and peaks of $\mathrm{s}-(+)$-carvone and limonene were reported in many reviews (Damian et al., 2003; Zapata et al., 2009; Fu and Lim, 2012; Obadiah et al., 2012), which were compared with CEO spectra obtained in this study (Figure 1). Zapata et al. (2009), Fu and Lim (2012) suggested that a strong bond appearing at $887 \mathrm{~cm}^{-1}$ was assigned to strong vibration out of plane of $=\mathrm{CH}_{2}$ group and was chosen for identifying limonene. Also, at $1673 \mathrm{~cm}^{-1}$ of the CEO spectra, not observed in the spectra of limonene, was noticed a peak typical for carvone spectra, assigned to vibration of $\mathrm{C}=\mathrm{O}$ bond, which is the main difference in molecule structure between carvone and limonene (Figure 1) (Obadiah et al., 2012).

FTIR spectra of pure chitosan film and chitosan film containing different concentrations of CEO showed the dominant absorption peaks and changes in spectra of pure chitosan, which are presented in Figure 2. The most dominant was chitosan spectra with typical peaks. In the following paragraphs are presented the main characteristic peaks of chitosan (Leceta et al., 2012; Hromiš et al., 2014) and changes caused by incorporating CEO into chitosan film.

- Interval at 3500-3000 $\mathrm{cm}^{-1}$ corresponds to stretching vibration of free hydroxyl group that overlaps the asymmetric and symmetric stretching of the $\mathrm{N}-\mathrm{H}$ bonds in amino group in the same region in chitosan spectra (Altiok et al., 2010; Siripatrawan and Harte, 2010; Martins et al., 2012; Zemljič et al., 2013). No significant differences were observed in chitosan spectrum after incorporating 1\% of CEO. However, when CEO was incorporated in concentrations of $2 \%$ and $3 \%$, the attenuation of peak was observed (Figure 2A). These results indicate that amino and hydroxyl functional groups, the most reactive groups of chitosan molecule, also decreased, probably due to some interactions with functional groups of CEO.

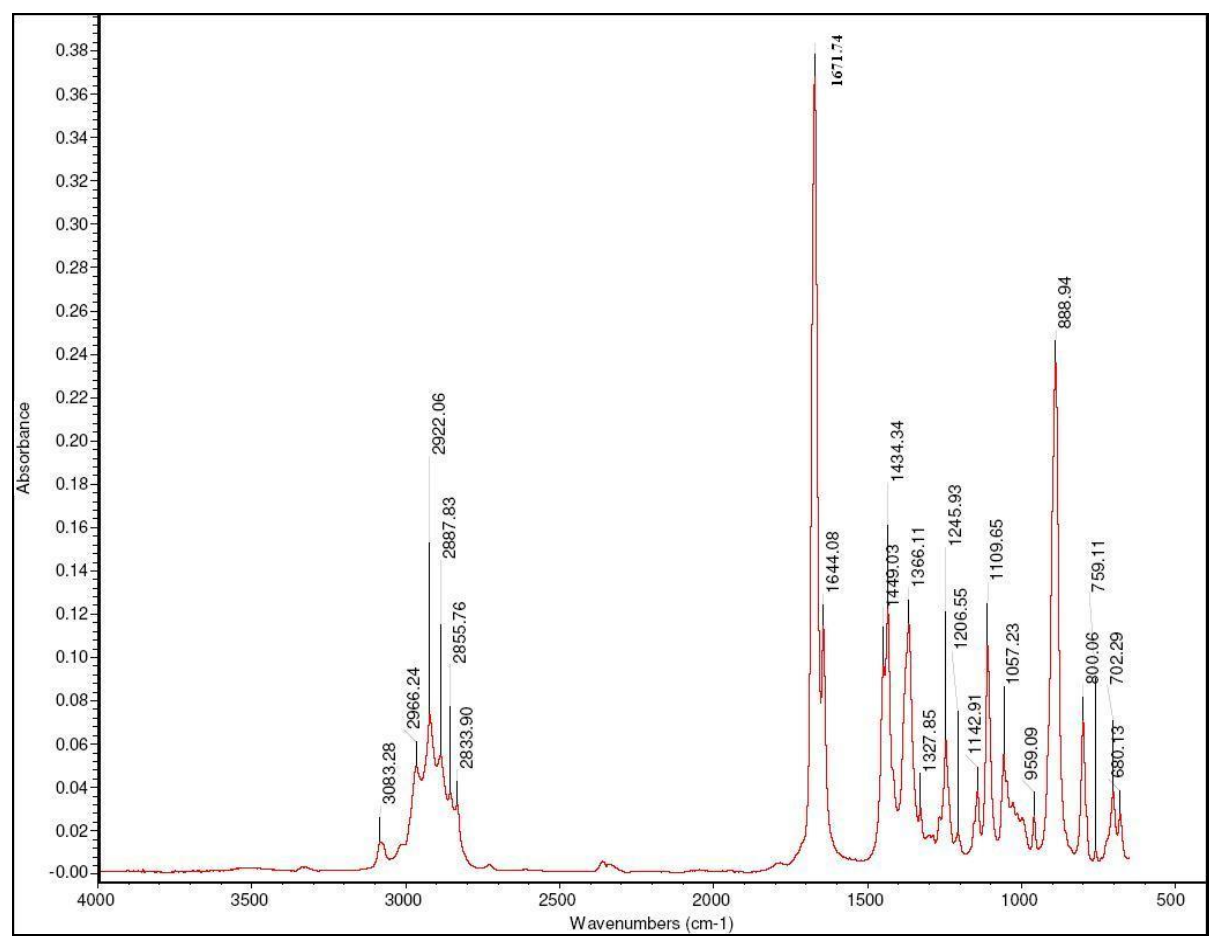

Figure 1. FTIR spectra of CEO with typical peaks of s-(+)-carvone and limonene 


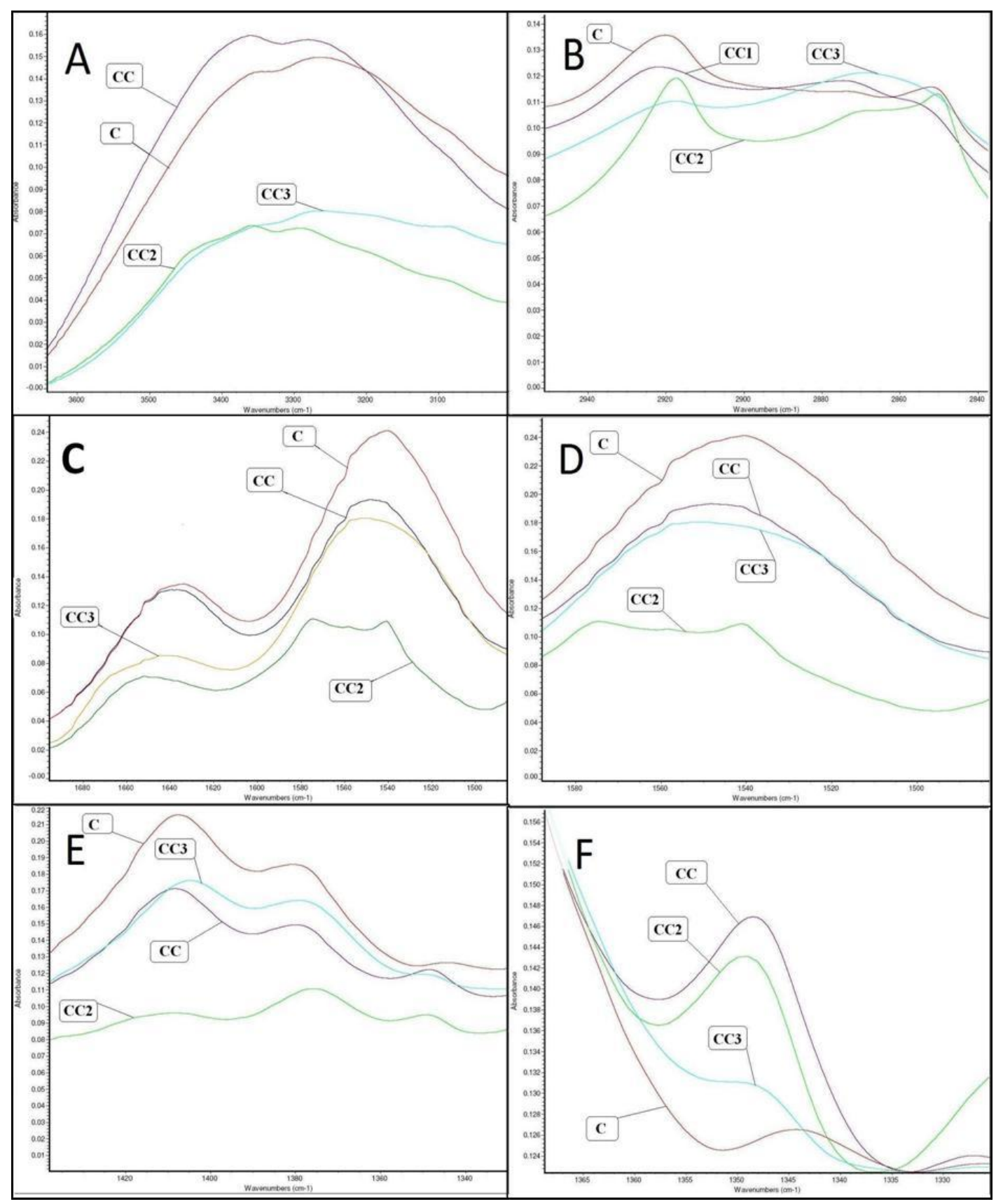

Figure 2. FTIR spectra of the changes in chitosan spectra after CEO was incorporated; A- interval $3500-3000 \mathrm{~cm}^{-1}$; B- interval 2950-2800 $\mathrm{cm}^{-1}$; C- peak at 1646 and $1580 \mathrm{~cm}^{-1}$; D- peak at $1540 \mathrm{~cm}^{-1}$; Epeak at $1410 \mathrm{~cm}^{-1} ; \mathrm{F}$ - peak at $1350 \mathrm{~cm}^{-1}$

- Interval at 2950-2800 $\mathrm{cm}^{-1}$ corresponds to $\mathrm{C}-\mathrm{H}$ stretching, from $-\mathrm{CH}_{2}$ group of chitosan molecule (Pranoto et al., 2005; Altiok et al., 2010; Martins et al., 2012; Zemljič et al., 2013). Incorporating CEO into chitosan film indicated significant changes in spectrum of CC2 film. The more pronounced peak, compared to peak in the control ( $C$ film) spectra, was observed (Figure 2B).

- A peak at $1646 \mathrm{~cm}^{-1}$ is assigned to the presence of carbonyl group $(\mathrm{C}=\mathrm{O})$ in chito- san film (Martins et al., 2012; Zemljič et al., 2013). Since the grade of chitosan used in the present study was around $80 \%$ deacetylated, the $\mathrm{C}=\mathrm{O}$ stretching (amide I) peak at $1650 \mathrm{~cm}^{-1}$ and $\mathrm{N}-\mathrm{H}$ bending (amide II) peak at $1580 \mathrm{~cm}^{-1}$ were observed. These peaks represent the structure of $\mathrm{N}$-acetylglucosamine, which could be found in chitosan with a lower degree of deacetylation (Altiok et al., 2010). No significant differences were observed between pure chitosan film and chitosan film 
with $1 \%(\mathrm{v} / \mathrm{v})$ of CEO. However, with increased concentration of CEO (CC2 and CC3 films), decrease of corresponding peaks was observed. This was probably because of some interactions that indicate decrease of carboxyl group in chitosan molecule and are correlated to strong stretching carbon-to-carbon $(\mathrm{C}=\mathrm{C})$ within the aromatic ring from compounds in CEO (Figure 2C) (Siripatrawan and Harte, 2010).

- A peak at $1540 \mathrm{~cm}^{-1}$ significantly decreased when CEO was incorporated into chitosan film, which was assigned to the secondary amide bending vibration $(\mathrm{N}-\mathrm{H}$ groups) in molecule of chitosan (Pranoto et al., 2005; Altiok et al., 2010; Martins et al., 2012; Zemljič et al., 2013) (Figure 2D).

- A peak at $1410 \mathrm{~cm}^{-1}$ corresponds to carboxyl groups (-COO-) associated with the antimicrobial activity of the biopolymer (Pranoto et al., 2005; Leceta et al., 2012). It was observed that peak significantly decreased when CEO was incorporated into chitosan film, which indicated the decreased number of carboxyl groups in chitosan molecule (Figure 2E).

- A new peak was observed at $1350 \mathrm{~cm}^{-1}$ after incorporation of CEO into chitosan film, which was attributed to the deformation of C-C bond. This peak is typical for all aromatic compounds, probably caused by presence of the aromatic compound from CEO, such as carvone and limonene (Figure 2F) (Damian et al., 2003).

These results suggested that incorporating CEO into chitosan film caused some changes in structure of chitosan molecule, probably caused by strong reactions and bonding between functional groups of chitosan and main components of CEO.

\section{Antioxidant activity}

The DPPH - radical scavenging activity of chitosan film without incorporated CEO (C film) and with 1\% (CC film), 2\% (CC2 film) and $3 \%$ (CC3 film) of incorporated CEO is presented in Figure 3. DPPH radical has been widely used to test the ability of compounds as free radical scavengers or hydrogen donors in order to evaluate the antioxidant activity (AO).
Many researches have confirmed $\mathrm{AO}$ of chitosan (Park et al., 2004; Yen et al., 2008). The scavenging mechanism of chitosan is related to the fact that free radical can react with the residual free amino $\left(\mathrm{NH}_{2}\right)$ groups to form stable macromolecule radicals, and the $\mathrm{NH}_{2}$ groups can form ammonium $\left(\mathrm{NH}^{3+}\right)$ ions by adsorbing a hydrogen ion from the solution (Park et al., 2004; Kim and Thomas 2007; Martins et al., 2012; Siripatrawan and Harte, 2010). In the present study pure chitosan film showed the lowest $A O$ of all tested films, and did not significantly changed ( $p>0.05)$ with the time in DPPH solution. Many investigations confirmed that chitosan with higher degree of deacetylation (DD) has more amino groups on $\mathrm{C}_{2}$ atom which increases its AO (Park et al., 2004; Yen et al., 2008). In the present study, chitosan with about $80 \%$ DD was used to produce film for scavenging ability investtigation. Park et al. (2004) suggested that $90 \%$ DD chitosan solution with concentration of $5 \mathrm{mg} / \mathrm{mL}$ and $75 \%$ DD chitosan of the same concentration, have achieved $38.72 \%$ and $35.52 \%$ of scavenging activity on DPPH radical, respectively. In this study, chitosan film with $80 \%$ of DD produced from the solution with concentration of $10 \mathrm{mg} / \mathrm{mL}$, after $24 \mathrm{~h}$ has achieved $29.95 \%$ of scavenging activity on DPPH radical, which is comparable to the results presented by Park et al. (2004). However, it must be noted that in the present research the AO was analyzed on chitosan in solid state (chitosan film) and not in solution, as in study of Park et al. (2004). Chitosan in solution has more available active groups responsible for antioxidant activity than chitosan in solid state.

Incorporating CEO in chitosan film enhanced $A O$ of pure chitosan film and it was observed that $A O$ significantly increased $(p<0.05)$ with incorporation of higher concentration of essential oil up to $2 \%$. In addition, AO of chitosan films with $1 \%$ CEO significantly increased with time in DPPH solution. Altiok et al. (2010) investigated the influence of time on releasing of essential oil from chitosan film in surrounding environment. The thyme essential oil was incorporated in chitosan film in concentrations of $0.2,0.4,1$ and $1.2 \%$ $(\mathrm{v} / \mathrm{v})$. ABTS test (ABTS anion radical sca- 


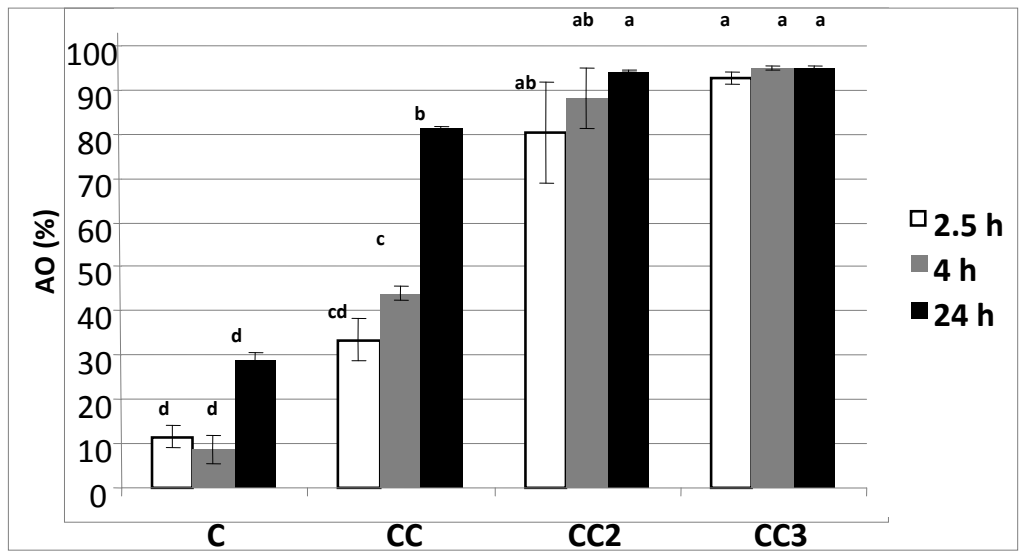

Figure 3. Antioxidant activity, $\mathrm{AO}(\%)$ of pure chitosan film (C) and chitosan film with incorporated $1 \%$ (CC), $2 \%$ (CC2) and 3\% (CC3) of CEO; Data are presented as mean value with their SD (error bars); abcd - different letters mark significantly different means with $95 \%$ probability $(p<0.05)$

venging activity) was used to observe $A O$ of tested films and releasing of essential oil from the films. The results suggested that pure chitosan film showed some AO and that thyme oil incorporation in concentration of $0.2 \%$ and $0.4 \%$ did not affect significantly the $\mathrm{AO}$ of chitosan film. However, incorporation of $1 \%$ and $1.2 \%$ of thyme essential oil caused four and eight times higher $A O$ compared to the control film. Those results also suggested that $A O$ of tested films and amount of released oil were directly proportional and that antioxidant compounds were released within $100 \mathrm{~s}$, except for chitosan film with $1.2 \%$ thyme oil where it took approximately 300 s (Altiok et al., 2010). In the present study, AO of chitosan film with $1 \%$ CEO was enhanced by releasing essential oil after $4 \mathrm{~h}$ and even further after $24 \mathrm{~h}$ (Figure 3).

Essential oils have ability to act as donors of hydrogen atoms or electrons in the transformation of DPPH into its reduced form (DPPH-H) (Samojlik et al., 2010). As mentioned before, main constituents of CEO, responsible for its activity, are s-(+)carvone and limonene. Samojlik et al. (2010) determined the AO of different concentrations of CEO using DPPH assay. Obtained result suggested that $\mathrm{CEO}$ in concentration of $10 \mu \mathrm{L} / \mathrm{mL}$ achieved the $\mathrm{AO}$ of $85.41 \%$ and that $\mathrm{AO}$ increased when higher concentration of CEO was incorporated. Concentration of $10 \mu \mathrm{L} / \mathrm{mL}$ is equivalent to CC1 film in this research and our results correspond to those presented by Samojlik et al. (2010) (84.23\%, after 24 h). Samojlik et al. (2010) also suggested that when the $\mathrm{AO}$ with lower concentration of CEO $(5 \mu \mathrm{L} / \mathrm{mL}$ and $7.5 \mu \mathrm{L} / \mathrm{mL})$ was analyzed, significant $\mathrm{AO}$ was obtained (58.75\% and $73.71 \%$ respectively). Martins et al. (2012) studied AO of pure chitosan film and chitosan film with incorporated $\alpha$-tocopherol to evaluate whether $\alpha$-tocopherol retained its $\mathrm{AO}$ after incorporation into film. $\alpha$-tocopherol is wellknown antioxidant substance, often used as a reference for comparison of results in studies. Obtained results showed that pure chitosan film showed activity of $10.69 \%$ on DPPH radical, which is slightly lower than results obtained in this study $(11.63 \%$, after $2.5 \mathrm{~h}$ ), while incorporating $0.1 \%$ and $0.2 \%$ of a-tocopherol increased $\mathrm{AO}$, reaching values of $97.42 \%$ and $97.71 \%$, respectively. Comparing those results with results obtained in the present study, it can be concluded that incorporating CEO into chitosan film caused high $\mathrm{AO}$ (more than $80 \%$ for CC1 film, after $24 \mathrm{~h}$ and $94.13 \%$ and $94.83 \%$ for CC2 and CC3 films, respectively, after $24 \mathrm{~h}$ ) which is slightly lower than the results obtained when $\alpha$-tocopherol was incorporated into chitosan film. In the study of Martins et al. (2012) no significant difference between the two a-tocopherol concentrations incor- 
porated in the films was observed. Those results are in line with results obtained in the present study for incorporation of CEO at the level of $2 \%$ and $3 \%$, where no significant difference in scavenging activity was observed after $24 \mathrm{~h}$. The results of this study also suggest that the concentration increase is reflected in faster activity achievement and that there is a capacity for oil incorporated in chitosan matrix to be released from chitosan film with the time, but that remaining oil rapidly migrates to the surface of the film and in the solution of DPPH. Hromiš et al. (2014) investigated influence of storage time on antioxidant activity of chitosan film with $1 \%$ of CEO and results revealed that storage did not affect $A O$ of this film after one month.

These findings suggest that chitosan film with $1 \%$ and $2 \%$ of CEO has great potential to be used as coating, and biofilm as packaging material because of high film stability. Based on AO investigation, using higher concentrations of CEO has no ground.

\section{Antimicrobial activity}

In this study, antimicrobial activity ( $A A)$ of chitosan film with addition of $1 \%, 2 \%$ and $3 \%$ of CEO, were tested against four bacteria: Escherichia coli and Listeria monocytogenes as representatives of Grampositive and Staphylococcus aureus and Salmonella Typhimurium as representtatives of Gram-negative bacteria. Escherichia coli and Staphylococcus aureus were selected as the most common model organisms for examination, and Listeria monocytogenes and Salmonella Typhimurium were selected as the most important for microbial safety of food. Chitosan film without incorporated CEO was used as a control. The degree of reduction of cell number of tested bacteria was investigated and only films that showed AA higher than $75 \%$, were considered to have significant inhibitory activity (Zemljič et al., 2012; Zemljič et al., 2013).

All chitosan films showed high activity against Escherichia coli (Figure 4A). Incorporating different concentrations of CEO in chitosan film did not cause significant difference in $A A(p>0.05)$, after
$24 \mathrm{~h}$. The increase of AA with increased concentration of CEO was observed only after $3 \mathrm{~h}$, especially in case of CC2 and CC3 films. Obtained results suggested that addition of $2 \%$ and $3 \%$ of CEO in chitosan film already led to maximum activity after 3 h. Slightly higher activity was observed against Staphylococcus aureus. All films showed AA higher than $75 \%$, already after 3 h. No significant difference ( $p>0.05)$ was observed after $24 \mathrm{~h}$ comparing $\mathrm{C}, \mathrm{CC}$, and $\mathrm{CC} 2$ films. CC3 film showed lower AA of all tested films. Incorporating CEO in chitosan film did not cause increase in $A A$, however, it must be noted that the control film showed high $A A$ against Staphylococcus aureus (>90\%, after $24 \mathrm{~h}$ ) and therefore the CEO activity could not be recorded (Figure 4B). The lowest activity of all tested films showed against Salmonella Typhimurium (Figure 4C). In contact with bacterial suspension, C, CC2 and CC3 film caused increase in bacterial cell number after $3 \mathrm{~h}$, and in case of control film (C) this trend continued after $24 \mathrm{~h}$. Incorporating CEO in chitosan film improved AA. The best activity was shown by the CC film, which did not cause increase in cell number in bacterial suspension, and showed significant antimicrobial activity after 24 h (>75\%). Degree of reduction for Listeria monocytogenes was presented only after $3 \mathrm{~h}$ because previous study showed that cells of Listeria monocytogenes can not survive in phosphate buffer $\mathrm{pH} 7.2$, which was used in this study, after $24 \mathrm{~h}$. It was observed that incorporation of CEO in chitosan film significantly increased $A A$, however increase of concentration did not affect further AA and no significant differences $(p>0.05)$ were observed comparing $\mathrm{CC}, \mathrm{CC} 2$ and CC3 films (Figure 4D).

These results suggested that contact time in bacterial suspension had a significant influence on AA. All films showed higher $\mathrm{AA}$ against tested bacteria after $24 \mathrm{~h}$ than after $3 \mathrm{~h}$. Better activity against Gram-positive than Gram-negative bacteria was observed, which is in line with previous studies (Coma et al., 2003; Kong et al., 2010; Dutta et al., 2012). The most sensitive bacteria was Staphylococcus aureus because all tested films showed excellent degree of reduction $(>75 \%)$. The most re- 


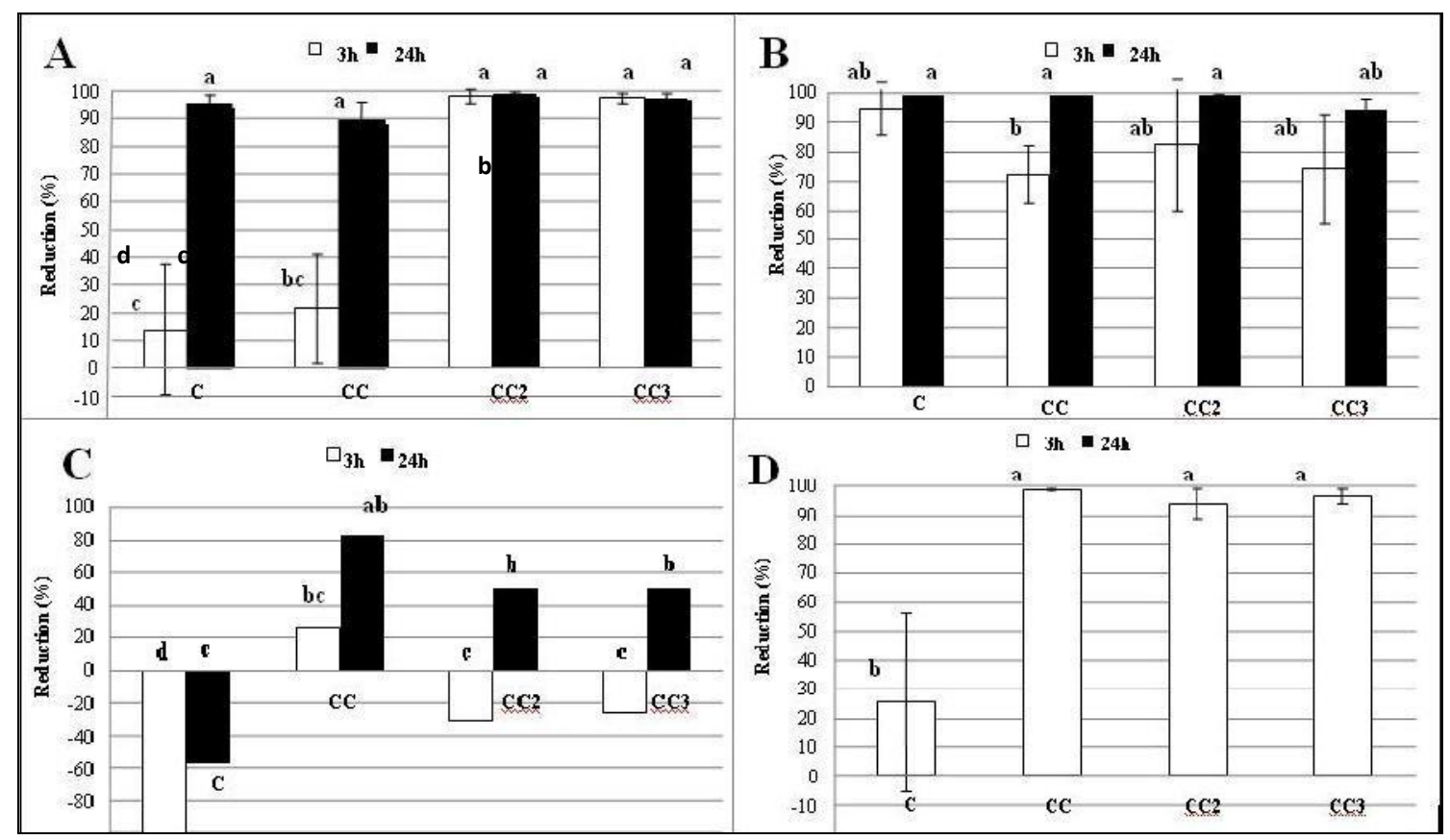

Figure 4. Antimicrobial activity of chitosan films against Escherichia coli (A), Staphylococcus aureus (B), Salmonella Typhimurium (C) and Listeria monocytogenes (D); All date are presented as mean value with their SD (error bars) except the results obtained for Salmonella Typhimurium due to nonreadability of the graph after placing error bars

sistant bacteria was Salmonella Typhimurium murium. Control film showed negative degree of reduction in contact with cell suspension and only chitosan film with $1 \%$ of incorporated CEO showed AA higher than $75 \%$.

Comparing obtained results of all investtigated chitosan films, it was concluded that the control film showed the lowest AA against tested bacteria. It caused increase of cell number after $3 \mathrm{~h}$ and $24 \mathrm{~h}$ in contact with cell suspension of Salmonella Typhimurium and showed the lowest AA against Escherichia coli and Listeria monocytogenes after $3 \mathrm{~h}$. Mechanism of AA of chitosan was reported in many papers which suggested that positively charged amino group in the molecule of chitosan plays the main role for its antimicrobial characterristics, as positively charged chitosan molecules interact with negatively charged bacteria causing disruption on the cell (Shahidi et al., 1999; Coma et al., 2003; Park et al., 2004). It was also suggested that chitosan in solution showed higher AA than chitosan in the solid state (chitosan films) because chitosan can not diffuse through matrix and only bacterial cells, which are in direct contact with active groups of chitosan, can be inhibited (Pranoto et al., 2005; Leceta et al., 2013). Incorporation of CEO at different concentrations into chitosan film improved the AA of the film. Many studies suggested that CEO has high AA because of the main components, s-(+)-carvone and limonene (Bailer et al., 2001; Aggarwal et al., 2002; Dimić et al., 2009). The results obtained in this study suggested that the best $A A$ showed chitosan film with $1 \%(\mathrm{v} / \mathrm{v})$ of incorporated CEO. This film showed AA higher than $75 \%$ against all tested bacteria and $A A$ was enhanced with contact time in cell solution.

\section{CONCLUSIONS}

Incorporation of caraway essential oil (CEO) in different concentrations into chitosan film caused some changes in appearance of chitosan film. The films were more yellow (except the film with the lowest concentration of CEO which was colorless as chitosan film), turbid, with odor of caraway and with some oil residue on the film surface with the highest concentration of CEO. These changes could influence possible application of these films as packaging material. Also, odor 
and residue oil on the surface of the film could affect sensory properties of packed product. The film with $1 \%$ CEO showed minimal changes in colour and odor and this film is most appropriate for food packaging. Films with higher concentrations of oil might affect visibility of packed product, as well as sensory properties and their application is limited to foodstuffs in which caraway odor would not be considered as a flaw.

Changes in structure of chitosan film after incorporating $\mathrm{CEO}$, which were obtained using FTIR, confirmed that there was interaction between functional groups of chitosan and CEO. Results for the antioxidant activity suggested that incorporating CEO into chitosan film significantly increased antioxidant activity of the film. Obtained results for the antimicrobial activity showed that pure chitosan film has potential as antimicrobial agent, but addition of optimal concentrations ( $1 \%-2 \%)$ of CEO increased antimicrobial activity of film even more. Results suggested that contact time in bacterial suspension, as well as radical solutions, have a significant influence on antimicrobial efficiency and better activity against Gram-positive than Gram-negative bacteria. The most sensitive bacteria was Staphylococcus aureus and the most resistant bacteria was Salmonella Typhimurium. Chitosan film with the lowest concentration of incorporated CEO (1\%) showed high antioxidant activity with gradual releasing of CEO from the film. Antimicrobial activity of this film was more than $75 \%$ against all tested bacteria and had the minimal impact on the appearance of the film. This recommends the film with $1 \%$ of caraway essential oil as the most appropriate for application as packaging material.

\section{ACKNOWLEDGEMENTS}

This study was supported by the Ministry of Education, Science and Technological Development of the Republic of Serbia, Project No. TR31032.

\section{REFERENCES}

1. Aggarwal, K. K., Khanuja, S. P. S., Ahmad, A., Santha Kumar, T. R., Gupta, V.K., Kumar, S. (2002). Antimicrobial activity profiles of the two enantiomers of limonene and carvone isolated from the oils of Mentha spicata and Anethum sowa. Flavour Fragrance Journal, 17, 59-63.

2. Almenar, E., Hernández-Muñoz, P., Gavara, R. (2009). Evolution of selected volatiles in chitosan-coated strawberries (Fragaria $x$ ananassa) during refrigerated storage. Journal of Agricultural and Food Chemistry, 57, 974-980.

3. Altiok, D., Altiok, E., Tihminlioglu, F. (2010). Physical, antimicrobial and antioxidant properties of chitosan films incorporated with thyme oil for potential wound healing applications. Journal of Materials Science: Materials in Medicine, 21(7), 2227-2236.

4. ASTM E2149 (2001). Standard Test Method for Determining the Antimicrobial Activity of Immobilized Antimicrobial Agents Under Dynamic Contact Conditions, American Society for Testing and Materials, PA, SAD.

5. Bailer, J., Aichinger, T., Hackl, G., De Hueber, K., Dachler, M. (2001). Essential oil content and composition in commercially available dill cultivars in comparison to caraway. Industrial Crops and Products, 14 (3), 229-239.

6. Casariego, A., Souza, B.W.S., Vicente, A.A., Teixeira, J.A., Cruz, L., Díaz, R. (2008). Chitosan coating surface properties as affected by plasticizer, surfactant and polymer concentrations in relation to the surface properties of tomato and carrot. Food Hydrocolloids, 22, 1452-1459.

7. Coma, V., Martial-Gros, A., Garreau, S., Copinet, A., Salin, F., Deschamps, A. (2002). Edible antimicrobial films based on chitosan matrix. Journal Of Food Science, 67(3), 11621169.

8. Coma, V., Deschamps, A., Martial-Gros, A. (2003). Bioactive packaging materials from edible chitosan polymer-antimicrobial activity assessment on dairy-related contaminants. Journal of Food Science, 68 (9), 2788-2792.

9. Damian, G., Miclăuş, V., Moldovan, I., Puia, M. (2003). Vibrational studies of absorption carvone on some surfaces. Studia Universitatis Babeş-Bolyai, Physica.

10. Dimić, G., Kocić-Tanackov, S., Pejin. D., Pejin, J., Tanackov, I., Tuco, D. (2009). Antimicrobial activity of caraway, garlic and oregano extract against filamentous moulds. Acta periodica technologica, 40, 1-220.

11. Dutta, J., Tripathi, S., Dutta, P.K. (2012). Progress in antimicrobial activities of chitin, chitosan and its oligosaccharides: a systematic study needs for food applications. Food Science and Technology International, 18 (1), 3-34.

12. Fajardo, P., Martins, J.T., Fucińos, C., Pastrana, L., Teixeira, J.A., Vicente, A.A. (2010). Evaluation of a chitosan-based edible film as carrier of natamycin to imrove the storability of Saloio cheese. Journal of Food Engineering, 101, 349-356.

13. Fu, Y., Lim, L. (2012). Investigation of multiplecomponent diffusion through LLDPE film using an FTIR-ATR technique. Polymer Testing, 31, 56-67. 
14. Gupta, D., Haile, A. (2007). Multifunctional properties of cotton fabric treated with chitosan and carboxymethyl chitosan. Carbohydrate Polymers, 69,164-171.

15. Hromiš, N., Lazić, V., Markov, S., Vaštag, Ž., Popović, S. and Šuput, D. (2014). Improvement of antioxidant and antimicrobial activity of chitosan film with caraway and oregano essential oils. Acta periodica technologica, 45, 1-283.

16. Kim, K., Thomas, R. (2007). Antioxidative activity of chitosans with varying molecular weights. Food Chemistry, 101 (1), 308-313.

17. Kurek, M., Moundanga, S., Favier, C., Galić, K., Debeaufort, F. (2013). Antimicrobial efficiency of carvacrol vapour related to mass partition coefficient when incorporated in chitosan based films aimed for active packaging. Food Technology, 32, 168-175.

18. Kong, M., Chen, X.G., Park, H.J. (2010). Antimicrobial properties of chitosan and mode of action: A state of the art review. International Journal of Food Microbiology, 144, 51-63.

19. Krkić, N., Šojić, B., Lazić, V., Petrović, Lj., Mandić, A., Sedej, I., Tomović, V. (2013). Lipid oxidative changes in chitosan-oregano coated traditional dry fermented sausage Petrovská klobása. Meat Science, 93, 767-770.

20. Leceta, I., Guerrero, P., Ibarburu, I., Dueńas M.T., De la Caba, K. (2013). Characterization and antimicrobial analysis of chitosan-based films. Journal of Food Engineering, 116, 889899.

21. Martins, J.T., Cerqueira, M.A., Vincente, A.A. (2012). Influence of a-tocopherol on physicochemical properties of chitosan-based films. Food Hydrocolloids, 27, 220-227.

22. Morales, F.J. and Jimenez-Perez, S. (2001). Free radical scavenging capacity of Maillard reaction products as related to colour and fluorescence. Food Chemistry, 72 (1), 119-125.

23. Obadiah, A., Kankan, R., Ramesh, P., Ramasubbu, A., Vasanth Kumar, S. (2012). Isolation of carvone and phellandrene from Murraya koenigii and study of their antioxidant activity. Chemistry of Natural Compounds, 48.

24. Park, P., Je, J. and Kim, S. (2004). Free radical scavenging activities of differently deacetylated chitosans using an ESR spectrometer. Carbohydrate Polymers, 55, 17-22.

25. Portes, E., Gardrat, C., Castellan A., Coma, V. (2009). Environmentally friendly films based on chitosan and tetrahydrocurcuminoid derivatives exhibiting antimicrobial and antioxidative properties. Carbohydrate Polymers, 76, 578-584.

26. Pranoto, Y., Rakshit, S.K., Salokhe, V.M. (2005). Enhancing antimicrobial activity of chitosan films by incorporating garlic oil, potassium sorbate and nisin. LWT - Food Science and Technology, 38 (8), 859-865.
27. Ruberto, G., Baratta, M.T. (2000). Antioxidant activity of selected essential oil components in two lipid model systems. Food Chemistry, 69, 167-174.

28. Ruiz-Navajas, Y., Viuda-Martos, M., Sendra, E., Perez-Alvarez, J.A., Fernández-López, J. (2013). In vitro antimicrobial and antioxidant properties of chitosan edible films incorporated with Thymus moroderi or Thymus piperella essential oils. Food Control, 30 (2), 386-392.

29. Samojlik, I., Lakić, N., Mimica-Dukić, N., Đaković-Švajcer, K., Božin, B. (2010). Antioxidant and hepatoprotective potential of essential oils of coriander (Coriandrum sativum L.) and caraway (Carum carvi L.) (Apiaceae). Journal of Agricultural and Food Chemistry, 58 (15), 8848-8853.

30. Sathivel, S., Liu, Q., Huang, J., Prinyawiwatkul, W. (2007). The influence of chitosan glazing on the quality of skinless pink salmon (Oncorhynchus gorbuscha) fillets during frozen storage. Journal of Food Engineering, 83, 366373.

31. Siripatrawan, U., Harte, B.R. (2010). Physical properties and antioxidant activity of an active film from chitosan incorporated with green tea extract. Food Hydrocolloids, 24, 770-775

32. Shahidi, F., Arachchi, J.K.V., Jeon Y. (1999). Food applications of chitin and chitosans. Trends in Food Science \& Technology, 10, 3751.

33. Wei, A., Shibamoto, T. (2007). Antioxidant activities and volatile constituents of various essential oils. Journal of Agricultural and Food Chemistry, 55 (5), 1737-1742.

34. Wu, Y.-B., Yu, S.-H., Mi, F.-L., Wu, C.-W., Shyu, S.-S., Peng, C.-K., Chao, A.C. (2004). Preparation and characterization on mechanical and antimicrobial properties of chitsoan/cellulose blends. Carbohydrate Polymers, 57, 435-440.

35. Yen, M., Yang, J., Mau, J. (2008). Antioxidant properties of chitosan from crab shells. Carbohydrate Polymers, 74 (4), 840-844.

36. Zapata, R.B., Villa, A.L., De Correa, C.M., Williams, C.T. (2009). In situ Fourier transform infrared spectroscopic studies of limonene epoxidation over PW-Amberlite. Applied Catalysis $A, 365,42-47$.

37. Zemljič, L.F., Sauperl, O., Kreze, T., Strand, S. (2012). Characterization of regenerated cellulose fibres antimicrobial functionalized by chitosan. Textile Research Journal, 83 (2), 185196.

38. Zemljič, L.F., Tkavc, T., Vesel, A., Šauperl, O. (2013). Chitosan coatings onto polyethilene terephtalate for the development of potential active packaging material. Applied Surface Science, 265, 697-703 


\section{АНАЛИЗА УТИЦАЈА ЕТАРСКОГ УЉА КИМА НА АНТИОКСИДАТИВНУ И АНТИМИКРОБНУ АКТИВНОСТ ХИТОЗАНСКОГ ФИЛМА}

Невена М. Хромиш, Сандра Н. Булут, Вера Л. Лазић, Сенка З. Поповић, Данијела 3. Шупут, Синиша Л. Марков, Жужана Г. Ваштаг, Наталија Р. Џинић

Универзитет у Новом Саду, Технолошки фракултет, 21000 Нови Сад, Булевар цара Лазара бр. 1, Србија

Сажетак: Циљ овог рада је био одређивање антиоксидативне и антимикробне активности хитозанског филма са додатком етарског уља кима. За одређивање интеракција функционалних група хитозана и етарског уља кима је коришћена Фуријева трансформишућа инфрацрвена спектроскопија. Утврђено је да нови детектовани пикови одговарају карвону и лимонену, односно компонентама које су у највећој количини присутне у киму. За одређивање антиоксидативне активности хитозанског филма коришћена је DPPH метода. Хитозански фрилм без етарског уља кима је показао најмању антиоксидативну активност (29,95\%, након 24 сата). Додатак етарског уља кима је значајно повећао антиоксидативну активност хитозанског филма и достигао максималну вредност од 95\%. За одређивање антимикробне активности хитозанског фрилма коришћена је ASTM E 2149-01 метода. Добијени резултати представљени су као степен редукције бактеријских ћелија у контакту са хитозанским филмовима. Као тест бактерије коришћене су грам позитивне бактерије Staphylococcus aureus и Listeria monocytogenes и грам негативне бактерије Escherichia coli и Salmonella Typhimurium. Као најосетљивија бактерија, на све хитозанске филмове, показала ce Staphylococcus aureus, а као најотпорнија Salmonella Typhimurium. Ови резултати показују да инкорпорирање етарског уља кима у хитозански филм значајно побољшава његову антиоксидатитвну и антимикробну активност и због тога има велики потенцијал као активни амбалажни материјал.

Кључне речи: хитозански фрилм, етарско уље кима, антиоксидативна активност, антимикробна активност

Received: 27 March 2015

Accepted: 29 May 2015 